\title{
ANALISIS KANDUNGAN NATRIUM NITRIT \\ PADA DAGING SAPI MENTAH DI PASAR DAN SUPERMARKET KOTA JAMBI
}

\author{
Lia Anggresani*, Armini Hadriyati, Angga Yuri Syahyara, Septa Pratama \\ STIKES Harapan Ibu Jambi; J1. Tarmizi Kadir No.71 Pakuan Baru Telp.(0741)7552270 \\ e-mail: anggresani@yahoo.com \\ Diterima: 10 Oktober 2018 / Disetujui: 07 Desember 2018 / Dipublikasi online: 15 Desember 2018 \\ DOI: $10.22437 /$ chp.v3i2.5726
}

\begin{abstract}
The analysis of sodium nitrite content in raw beef from traditional market and supermarket in Jambi City using spectrophotometry UV-Vis has been investigated. In the processing meat, the nitrite can inhibit the growth of clostridium botalinum bacteria, maintain the red color and give the flavor. If consumed the excess nitrite can caused carcinogens and can be poisoned. The aim of this research was to determined the content of sodium nitite in raw beef from market The analytical method used is qualitative analysis using various reagents and quantitative analysis using Griess reagents. The griess reagent will form a colored compound and its absorbance is measured at a wavelength of $545.5 \mathrm{~nm}$. The sample comes from 7 traditional markets and 1 supermarket. The results showed the levels of sodium nitrite in raw beef samples $A=0.002 \%, B=0.0007 \%, C=0.0006 \%, D=0.001 \%, E=0.001 \%, F=0.001 \%, G=$ $0.0008 \%$, and $H=0,0009 \%$. It can be concluded that the levels of sodium nitrite in raw beef in the market and supermarket of Jambi city do not exceed the levels permitted by the Food and Drug Supervisory Agency, which is $30 \mathrm{mg} / \mathrm{kg}$ or $0.003 \%$.
\end{abstract}

Keywords: Sodium Nitrite, Raw Beef, Spectrophotometry UV-Vis

\section{ABSTRAK}

Telah dilakukan penelitian tentang analisa kandungan natrium nitrit pada daging sapi mentah di pasar dan supermarket kota Jambi secara spektrofotometri UV - Vis. Nitrit dalam pengolahan daging merupakan pengawet yang dapat menghambat pertumbuhan bakteri clostridium botalinum, mempertahankan warna merah pada daging dan sebagai pemberi cita rasa. Nitrit jika dikonsumsi berlebihan menyebabkan karsinogenik dan bisa keracunan. Tujuan penelitian ini untuk mengetahui kadar kandungan natrium nitrit pada daging sapi mentah di pasar dan supermarket kota Jambi. Metode analisa yang digunakan adalah analisa kualitatif menggunakan berbagai pereaksi dan analisa kuantitatif menggunakan pereaksi Griess. Pereaksi griess akan membentuk suatu senyawa berwarna dan diukur absorbansinya pada panjang gelombang $545,5 \mathrm{~nm}$. Sampel berasal dari 7 pasar tradisional dan 1 supermarket. Hasil penelitian menunjukkan kadar natrium nitrit pada daging sapi mentah sampel $A=0,002 \%, B=0,0007 \%, C=0,0006 \%, D=0,001 \%, E=0,001 \%, F=0,001 \%$, $G=0,0008 \%$, dan $H=0,0009 \%$. Dapat disimpulkan kadar natrium nitrit pada daging sapi mentah di pasar dan supermarket kota Jambi tidak melebihi kadar yang diizinkan Badan Pengawas Obat Dan Makanan yaitu sebesar $30 \mathrm{mg} / \mathrm{kg}$ atau 0,003\%.

Kata Kunci: Natrium Nitrit, Daging Sapi, Spektrofotometri UV-Vis

\section{PENDAHULUAN}

Pangan merupakan segala sesuatu yang berasal dari sumber hayati produk pertanian, perkebunan, kehutanan, perikanan, peternakan, perairan, dan air, baik yang diolah maupun tidak diolah yang dikonsumsi manusia, termasuk bahan tambahan pangan, bahan baku pangan, dan bahan lainnya yang digunakan dalam proses penyiapan, pengolahan, dan/atau pembuatan makanan atau minuman (Badan POM RI, 2013). Daging merupakan salah satu jenis pangan yang banyak di gemari oleh masyarakat untuk diolah 
menjadi berbagai macam masakan yang enak, Kualitas daging segar menurut konsumen pada umumnya masih berdasarkan karakteristik pancaindera dan organoleptik (Prasetyo \& Kendriyanto, 2010). Tingkat pengetahuan yang rendah mengenai bahan tambahan pangan merupakan faktor utama penyebab penggunaan boraks, formalin maupun penambahan nitrit yang berlebihan pada bahan pangan. Hal tersebut juga ditunjang oleh prilaku konsumen yang cenderung untuk membeli makanan yang harga murah tanpa mengutamakan kualitas sehingga penggunaan bahan tambahan pangan dianggap sebagai hal biasa (Cahyadi, 2008).

Cahyadi (2008) menyatakan bahwa Tujuan penggunaan nitrit dalam pengolahan daging adalah untuk menghambat pertumbuhan bakteri clostridium botalinum, mempertahankan warna merah pada daging agar menarik, dan juga sebagai pemberi cita rasa pada daging. Penggunaan natrium nitrit secara berlebihan tenyata menimbulkan efek yang membahayakan bagi kesehatan, natrium nitrit dapat bereaksi dengan amine sekunder dan tersier membentuk nitrosamine yang merupakan senyawa penyebab kanker. Pembentukan nitrosamin dapat terjadi pada makanan dalam suasana asam lambung (Rohman \& Sumantri, 2007). Konsumsi daging yang memiliki kadar nitrit berlebih dapat menyebabkan toksisitas akut maupun kronik menurut Nur Habibah et al... (2018)

Gomez et al. (2015) menyatakan bahwa natrium nitrit dan natrium nitrat sering ditambahkan pada produk daging olahan sebagai bahan pengawet. Natrium klorida dan nitrit dapat menghambat pertumbuhan bakteri Clostridium botulinum sehingga dapat memperlama masa simpan produk. Nitrit merupakan pilihan utama dalam proses pengawetan dan curing daging dikarenakan dapat memberikan hasil daging yang baik. Penelitian terkait kandungan nitrit pada daging olahan di wilayah Denpasar dengan metode Spektrofotometri UV-Vis telah dilakukan. Nur Habibah et al. (2018) menyatakan bahwa dari 18 sampel daging olahan yang diteliti terdapat 6 sampel yang memiliki kandungan nitrit di atas ambang batas yang telah ditetapkan pemerintah.

Pada penelitian ini, peneliti tertarik untuk mengidentifikasi Natrium Nitrit pada daging sapi mentah di supermarket dan pasar tradisional Kota Jambi dengan menggunakan Spektrofotometri UV-VIS dan menetapkan kadar natrium nitrit tersebut apakah melebihi batas maksimum dari Peraturan Badan Pengawas Obat dan Makanan Republik Indonesia Nomor 36 Tahun 2013 Tentang Batas Maksimum Penggunaan Bahan Tambahan Pangan Pengawet, batas maksimum penggunaan kalium nitrit atau natrium nitrit pada produk-produk olahan daging, daging unggas dan daging hewan buruan dalam bentuk utuh atau potongan yaitu $30 \mathrm{mg} / \mathrm{kg}$ atau $0,003 \%$.

\section{METODOLOGI PENELITIAN}

\section{Instrumentasi dan Bahan}

Metode penelitian ini adalah dilakukan secara eksperimental dengan menggunakan Spektrofotometri UV-Vis. Alat yang digunakan dalam penelitian ini Spektrofotometri UV-Vis (Shimatsu), Blender (Philips), rak tabung reaksi, pipet takar (Pyrex), tabung reaksi (Pyrex), 
labu ukur (Pyrex), beaker glass (Pyrex), botol semprot, pisau, spatel, kertas saring (Whatman 42), corong, karet hisap, pipet tetes, alat sentrifus (EBA 20S), penangas air, hot plate, dan timbangan analitik (Shimadsu). Bahan yang digunakan adalah daging sapi mentah, aquadest, asam sulfat, besi (II) sulfat, barium klorida, kalium iodida, larutan amilum jagung, perak nitrat, kalium permanganat, natrium nitrit.

\section{Metode Penelitian}

Ektraksi Sampel

Sebanyak $10 \mathrm{~g}$ sampel ditimbang dan dihaluskan dengan blender, dimasukkan dalam beaker glass $100 \mathrm{~mL}$. Sampel selanjutnya ditambah dengan $10 \mathrm{~mL}$ aquadest, lalu dimasukan kedalam tabung reaksi, lalu disentrifus dengan kecepatan 3000 rpm selama 20 menit, sehingga sampel akan memisah menjadi 2 bagian, kemudian dilakukan penyaringan. Maka larutan ini merupakan larutan sampel yang digunakan untuk uji kualitatif.

\section{Analisa Kualitatif}

(1) $\mathrm{FeSO}_{4}$ : Dua tetes larutan sampel direaksikan dengan FeSO4 lalu teteskan H2SO4 melalui dinding tabung reaksi, amati perubahan yang terjadi. Terbentuk cincin coklat pada perbatasan antara dua cairan sampel menunjukkan positif nitrit. (2) $\mathrm{BaCl}_{2}$ : Dua tetes larutan sampel direaksikan dengan 2 tetes larutan $\mathrm{BaCl} 2$, amati perubahan yang terjadi. Tidak terbentuk endapan, menunjukkan positif nitrit. (3) $\mathrm{AgNO}_{3}$ : Dua tetes larutan sampel direaksikan dengan 2 tetes larutan AgNO3 0,1 N, amati perubahan yang terjadi. Terbentuk endapan putih, menunjukkan positif nitrit. (4) KI: Dua tetes larutan sampel direaksikan dengan 2 tetes larutan $\mathrm{KI} 0,1 \mathrm{~N}$, kemudian diasam kan dengan asam asetat atau asam sulfat encer yang dapat diidentifikasi dari warna biru yang dihasilkan dengan larutan amilum jagung menunjukkan positif nitrit. (5) $\mathrm{KMnO}_{4}$ : Dua tetes larutan sampel direaksikan dengan 2 tetes larutan $\mathrm{KMnO} 4$ yang diasamkan dengan asam sulfat encer. Amati perubahan yang terjadi. Hilangnya warna ungu $\mathrm{KMnO} 4$ menunjukkan positif nitrit. Analisa Kuantitatif

\section{Pembuatan larutan pereaksi Griess}

Larutan I disiapkan dengan melarutkan 1 gram asam sulfanilat dalam $100 \mathrm{~mL}$ asam asetat 30\% v/v. Larutan II disiapkan dengan mendidihkan 0,3 gram N-1-naftiletilendiamonium dalam $70 \mathrm{~mL}$ aquadest sampai larut dan menuangkannya dalam keadaan panas ke dalam $30 \mathrm{~mL}$ asam asetat glasial. Kemudian larutan I dan larutan II dicampurkan dengan perbandingan 1 : 1 dengan volume akhir $100 \mathrm{~mL}$ dalam wadah botol berwarna coklat.

\section{Pembuatan larutan baku natrium nitrit}

Ditimbang sebanyak $100 \mathrm{mg}$ Natrium Nitrit kemudian dilarutkan dengan aquadest sampai volumenya tepat $100 \mathrm{~mL}$ hingga diperoleh konsentrasi $1000 \mathrm{ppm}$. Dari konsentrasi 1000 ppm diambil $10 \mathrm{~mL}$ dilarutkan dalam $100 \mathrm{~mL}$ aquadest hingga diperoleh konsentrasi 
$100 \mathrm{ppm}$ diambil $1 \mathrm{~mL}$ dilarutkan dalam $10 \mathrm{~mL}$ aquadest hingga diperoleh konsentrasi 10 ppm.

\section{Pembuatan seri konsentrasi baku natrium nitrit}

Dari larutan baku 10 ppm dipipet 1,$0 ; 1,4 ; 1,8 ; 2,2 ; 2,6 ; 3,0 \mathrm{~mL}$ dan diencerkan dengan aquadest sampai volumenya tepat $10 \mathrm{ml}$ sehingga diperoleh seri konsentrasi 1,0 ; 1,$4 ; 1,8 ; 2,2 ; 2,6$ dan 3,0 ppm

\section{Penentuan panjang gelombang}

Larutan baku natrium nitrit konsentrasi $1,0 \mathrm{ppm}$, diambil $10 \mathrm{~mL}$ dan ditambah $2 \mathrm{~mL}$ pereaksi Griess kemudian dibaca absorbansinya pada $\lambda$ 400-800 $\mathrm{nm}$. Diperoleh panjang gelombang yang memberikan absorbansi maksimum.

\section{Pembuatan kurva baku}

Larutan baku natrium nitrit dengan konsentrasi 1,$0 ; 1,4 ; 1,8 ; 2,2 ; 2,6$ dan 3,0 ppm, masing - masing diambil $10 \mathrm{~mL}$ dan ditambahkan $2 \mathrm{~mL}$ pereaksi Griess. Larutan dibiarkan selama operating time kemudian dibaca absorbansinya dengan menggunakan spektrofotometer UV-Vis pada $\lambda$ max. Data hasil absorbansi selanjutnya dibuat kurva baku sehingga diperoleh persamaan garis $\mathrm{y}=\mathrm{bx}+\mathrm{a}$.

Penetapan kadar natrium nitrit

Sebanyak 5 g sampel ditimbang secara seksama dan dihaluskan, dimasukkan dalam labu takar $50 \mathrm{~mL}$. Sampel selanjutnya ditambahkan dengan aquadest yang telah dipanaskan pada suhu $80^{\circ} \mathrm{C}$ hingga tanda batas, lalu di kocok beberapa saat dan disaring, Sebanyak $5 \mathrm{~mL}$ larutan hasil penyaringan dipipet lalu dimasukkan ke dalam labu takar 10 $\mathrm{mL}$, diencerkan dengan aquadest sampai tanda batas dan ditambah $2 \mathrm{~mL}$ pereaksi Griess. Larutan dibiarkan selama operating time dan dibaca absorbansinya pada $\lambda$ max.

\section{PEMBAHASAN}

Sampel daging sapi mentah didapatkan dari tujuh pasar tradisional dan satu supermarket yang ada di Kota Jambi. Pengujian sampel daging dilakukan secara kualitatif dan kuantitatif. Vogel (1990) menyatakan untuk uji kualitatif dapat dilakukan dengan beberapa pereaksi yaitu $\mathrm{FeSO}_{4}, \mathrm{BaCl}_{2}, \mathrm{AgNO}_{3}, \mathrm{KI}$ dan $\mathrm{KMnO}_{4}$. Dapat dilihat dari tabel 1 bahwa sampel A dan P (Pembanding) menunjukkan hasil yang positif memiliki kandungan natrium nitrit dengan beberapa pereaksi.

Tabel 1. Analisa kualitatif dengan beberapa pereaksi

\begin{tabular}{llllllllll}
\hline Pereaksi & \multicolumn{9}{c}{ Sampel } \\
& P & A & B & C & D & E & F & G & H \\
\hline $\mathrm{FeSO}_{4}$ & + & + & + & + & + & + & + & + & + \\
$\mathrm{BaCl}_{2}$ & + & + & + & + & + & + & + & + & + \\
$\mathrm{AgNO}_{3}$ & + & + & - & - & - & - & - & - & - \\
$\mathrm{KI}$ & + & + & - & - & - & - & - & - & - \\
$\mathrm{KMnO}_{4}$ & + & + & - & - & - & - & - & - & - \\
\hline Ket $:(+)=$ mengandung Natrium Nitrit; $(-)=$ Tidak mengandung Natrium Nitrit
\end{tabular}

Semua sampel setelah dianalisa secara kualitatif juga dilakukan analisa secara kuantitatif dengan menggunakan spektrofotometri UV-Vis guna untuk melihat ada atau 
tidaknya kandungan nitrit dan menetapkan kadar dari natrium nitrit. Pemeriksaan natrium nitrit secara kuantitatif menggunakan pereaksi Griess. Pada metode Griess, analisa kadar nitrit dilakukan berdasarkan pada reaksi diazotasi dari suatu amina aromatik dengan nitrit dalam suasana asam, yang diikuti dengan reaksi kopling sehingga menghasilkan senyawa azo yang berwarna merah (Agustina et al., 2016). Senyawa azo tersebut diukur absorbansinya pada rentang panjang gelombang 500-600 nm, sehingga kadar nitrit dapat ditentukan.

Penentuan panjang gelombang maksimum didapatkan pada 545,5 $\mathrm{nm}$ dengan menggunakan spektrofotometri UV-Vis (Gambar 1). Menurut Romsiah et al. (2017) menyatakan bahwa panjang gelombang maksimum dari larutan baku nitrit pada penetapan kadar nitrit pada sosis sapi di swalayan kota Palembang diperoleh pada panjang gelombang $540 \mathrm{~nm}$.

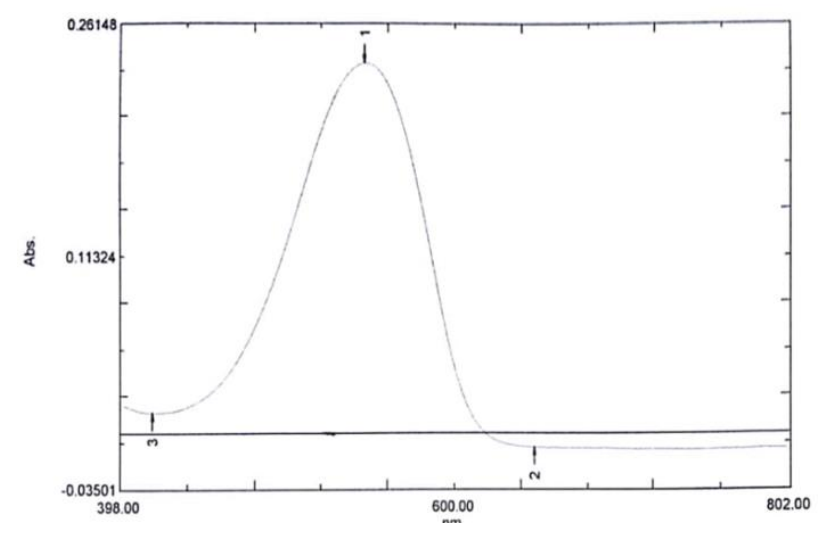

Gambar 1. Panjang gelombang maksimum larutan baku natrium nitrit $545,5 \mathrm{~nm}$

Persamaan kurva kalibrasi (linearitas) menunjukkan hubungan antara konsentrasi larutan standar dengan absorbansi. Pengukuran kurva kalibrasi diukur pada seri konsentrasi yang berbeda-beda yaitu 1 ppm, 1,4 ppm, 1,8 ppm, 2,2 ppm, 2,6 ppm dan 3 ppm. Dari kurva kalibrasi didapatkan persamaan regresi (Tabel 2) yaitu y $=0,262 x-0,049$ dengan nilai korelasi $(r)=0,999$ yang menunjukkan linearitas yang sangat baik.

Tabel 2. Nilai Absorbansi Seri Konsentrasi Larutan Baku Natrium Nitrit

\begin{tabular}{ccc}
\hline No & Konsentrasi & Absorban \\
\hline 1 & $1 \mathrm{ppm}$ & 0,209 \\
2 & $1,4 \mathrm{ppm}$ & 0,317 \\
3 & $1,8 \mathrm{ppm}$ & 0,433 \\
4 & $2,2 \mathrm{ppm}$ & 0,521 \\
5 & $2,6 \mathrm{ppm}$ & 0,627 \\
6 & $3,0 \mathrm{ppm}$ & 0,739 \\
\hline
\end{tabular}

Selanjutnya dilakukan pengukuran kadar dari natrium nitrit pada semua sampel daging. Berdasarkan hasil pengukuran absorban maka diperoleh hasil analisa kadar nitrit dari semua sampel daging adalah sebagai berikut (Tabel 3).

Dari hasil penetapan kadar natrium nitrit yang terdapat dalam sampel, dapat dilihat tidak melebihi batas maksimum dari Peraturan Badan Pengawas Obat dan Makanan Republik Indonesia Nomor 36 Tahun 2013 Tentang Batas Maksimum 
Penggunaan Bahan Tambahan Pangan Pengawet, batas maksimum penggunaan kalium nitrit atau natrium nitrit pada produk-produk olahan daging, daging unggas dan daging hewan buruan dalam bentuk utuh atau potongan yaitu $30 \mathrm{mg} / \mathrm{kg}$ atau $0,003 \%$.

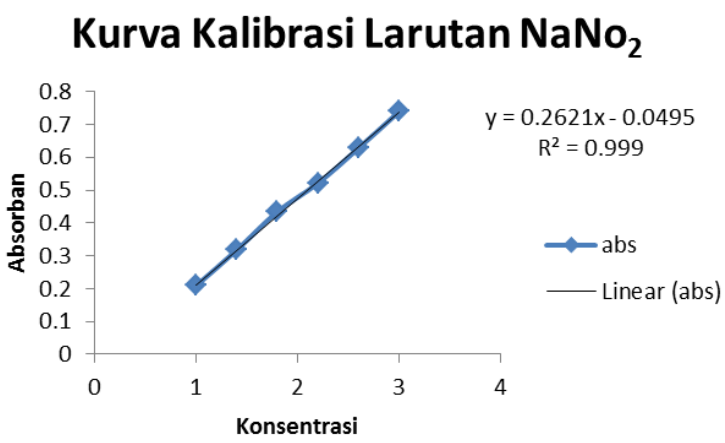

Gambar 2. Kurva Kalibrasi Larutan Baku Natrium Nitrit

Pada penelitian sebelumnya yang telah dilakukan oleh rusdi et al (2015), natrium nitrit juga ditemukan pada daging sapi di kota padang dengan kadar yang tidak melebihi batas maksimal penggunan natrium nitrit. Hal yang sama juga didapatkan pada penelitian Joe Armando Lukas et al (2016), ditemukannya natrium nitrit pada ayam crispy di kota manado dengan kadar yang masih pada batas yang diperbolehkan.

Tabel 3. Nilai Absorban dan Kadar Nitrit sampel daging

\begin{tabular}{|c|c|c|c|c|}
\hline \multirow[t]{2}{*}{ No } & \multirow[t]{2}{*}{ Sampel } & \multicolumn{2}{|c|}{ Absorban } & \multirow{2}{*}{$\begin{array}{c}\text { Kadar Natrium } \\
\text { Nitrit (\%) }\end{array}$} \\
\hline & & Pengulangan & Rata - Rata & \\
\hline \multirow[t]{3}{*}{1} & Sampel A & 1. 0,22679 & & \\
\hline & & 2. 0,22699 & 0,226 & \\
\hline & & 3. 0,22720 & & $0,002 \%$ \\
\hline \multirow[t]{3}{*}{2} & Sampel B & 1. 0,04420 & & \\
\hline & & 2. 0,04266 & & \\
\hline & & 3. 0,04312 & 0,043 & $0,0007 \%$ \\
\hline \multirow[t]{3}{*}{3} & Sampel C & 1. 0,04123 & & \\
\hline & & 2. 0,04124 & & \\
\hline & & 3. 0,04124 & 0,041 & $0,0006 \%$ \\
\hline \multirow[t]{3}{*}{4} & Sampel D & 1. 0,09969 & & \\
\hline & & 2. 0,09969 & & \\
\hline & & 3. 0,09969 & 0,099 & $0,001 \%$ \\
\hline \multirow[t]{3}{*}{5} & Sampel E & 1. 0,09108 & & \\
\hline & & 2. 0,09114 & & \\
\hline & & 3. 0,09132 & 0,091 & $0,001 \%$ \\
\hline \multirow[t]{3}{*}{6} & Sampel F & 1. 0,09752 & & \\
\hline & & 2. 0,09749 & & \\
\hline & & 3. 0,09741 & 0,097 & $0,001 \%$ \\
\hline \multirow[t]{3}{*}{7} & Sampel G & 1. 0,06050 & & \\
\hline & & 2. 0,06052 & & \\
\hline & & 3. 0,06056 & 0,060 & $0,0008 \%$ \\
\hline \multirow[t]{3}{*}{8} & Sampel H & 1. 0,07808 & & \\
\hline & & 2. 0,07191 & & 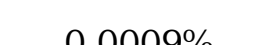 \\
\hline & & 3. 0,07182 & 0,073 & $0,0009 \%$ \\
\hline
\end{tabular}




\section{KESIMPULAN}

Berdasarkan hasil penelitian ini dapat disimpulkan bahwa daging sapi mentah yang beredar di pasar dan supermarket kota Jambi mengandung natrium nitrit. Kadar kandungan natrium nitrit yang didapatkan berada dibawah batas maksimum dari Peraturan Badan Pengawas Obat dan Makanan Republik Indonesia yaitu dibawah 30 $\mathrm{mg} / \mathrm{kg}$ atau $0,003 \%$.

\section{DAFTAR PUSTAKA}

Agustina, I., Astuti, I., dan Sopina, Y. 2016. Analisa Kimia Kandungan Natrium Nitrit pada Daging Burger yang Beredar di Pasar Kecamatan Duren Sawit Jakarta Timur. Indonesia Natural Research Pharmaceutical Journal. 1(1):43-54.

BPOM RI, 2013, Peraturan Kepala BPOM RI No 36 Tahun 2013 Tentang Batas Maksimum Penggunaan Bahan Tambahan Pangan Pengawet, Menkumham RI, Jakarta.

Cahyadi, W. 2008. Analisis dan Aspek Kesehatan Bahan Tambahan Pangan. Edisi Ke-2. PT. Bumi Aksara: Jakarta.

Habibah, N., Dhyanaputri, I.G.A.S., Karta, I.W., dan Dewi, N.N.A.D., 2018. Analisis Kuantitatif Kadar Nitrit dalam Produk Daging Olahan di Wilayah Denpasar Dengan Metode Griess Secara Spektrofotometri. International Journal of natural Sciences and Engineering. 2(1), 1-9.

Gomez, J., Sanjuan, N., Bon, J., Arnau, J., and Clemente, G,. 2015. Effect of Temperature on Nitrite and Water Diffusion in Pork Meat. Journal of Food Engineering, 149, 188194.

Lukas, J, Abidjulu, A.J., Yamlean, P., 2016. Analisis Kandungan Natrium Nitrit Pada Ayam Crispy Di Kota Manado. Pharmacon Jurnal Imiah Farmasi - UNSRAT. 5(4), 182-191.

Prasetyo, A \& Kendriyanto. 2010. Kualitas Daging Sapi Dan Domba Segar Yang Disimpan Pada Suhu Dingin Dengan Pengawet Asap Cair. Ungaran: Balai Pengkajian Teknologi Pertanian Jawa Tengah.

Rohman, A Sumantri. 2007. Analisis Makanan. Yogyakarta: Gadjah Mada University Press.

Rusdi. Z., Nurrohman, I.S., 2015. Analisis Pengawet Nitrit Pada Daging Sapi Dengan Spektrofotometri UV-Vis. Jurnal Farmasi Higea. 7(1), 101-110.

Romsiah. M., Sintya L., dan Fatoni, A., 2017. Validasi Metode dan Penetapan Kadar Nitrit (NO2-) pada Sosis Sapi Curah dan Sosis Sapi Kaleng yang Dijual Di Swalayan Kota Palembang Secara Spektrofotometri UV-Vis. Scientia Jurnal Farmasi dan Kesehatan. 7(2), 113-119.

Vogel. 1985. Buku Teks Analisis Anorganik Kualitatif Makro dan Semimikro Bagian II, Jakarta: PT. Kalman Media Pustaka. 